Petra Božanić, naslovni asistent

Prihvaćen: 23. lipnja 2021.

Filozofski fakultet Sveučilišta u Splitu

Odsjek za hrvatski jezik i književnost

petboz@ffst.hr

\title{
OBRADA VOKATIVNIH OBILJEŽJA U SUVREMENIM UDŽBENICIMA I ŠKOLSKIM GRAMATIKAMA HRVATSKOGA JEZIKA
}

Sažetak: Cilj je ovoga rada na korpusu aktualnih udžbenika hrvatskoga jezika za osnovnu i srednju školu, odabranih prema Konačnom rezultatu odabira udžbenika iz „,Kataloga odobrenih udžbenika u školskoj godini 2020./2021. osnovne škole“ i Konačnom rezultatu odabira udžbenika iz „Kataloga odobrenih udžbenika u školskoj godini 2020./2021. - srednje škole“, te četirima suvremenim školskim gramatikama hrvatskoga jezika autora Silića i Pranjkovića (2007), Težaka i Babića (2016), Ham (2017) te Hudeček i Mihaljević (2019), analizirati obradu vokativa i kategorije vokativnosti u okviru nastavnoga predmeta Hrvatski jezik s obzirom na vokativna fonetska, fonološka, morfološka, sintaktička, pravopisna i pragmatičko-semantička obilježja. Rezultati istraživanja upućuju na predstavljanje vokativa kao padeža u kontekstu formalno-gramatičkoga pristupa s isticanjem njegovih oblikotvornih obilježja i sintakticke autonomije, a komunikacijske vokativne funkcije u okviru funkcionalne jezikoslovne paradigme gotovo su posve zanemarene.

Ključne riječi: hrvatski jezik u nastavi, padeži, vokativ

\section{UVOD}

Kategorija vokativnosti, uz kategorije imperativnosti te interogativnosti, dio je kategorije apelativnosti kojom se recipijentova pozornost skreće na adresata ili poruku samu, stoga se vokativ može definirati kao gramatički oblik kategorije vokativnosti (Karlić i Cvitković, 2017, str. 228-229). Vokativu se svojstvo padeža dodaje kada je oblik obraćanja, kao svojstveno obilježje semantičko-pragmatičke kategorije vokativnosti, uključen u padežni sustav određenoga jezika (Daniel i Spencer, 2012, str. 626) ostvarujući se specifičnim vokativnim ili nominativnim gramatičkim morfemima (Karlić i Okuka, 2015, str. 32), no poseban gramatički morfem ne uvjetuje opstojnost vokativnih izraza 
u određenome jeziku, stoga vokativ kao padež nije nužno gramatikaliziran u svim jezicima (Karlić i Cvitković, 2017, str. 228). Osim oblikotvorne specifičnosti, vokativ se u pisanome diskursu raspoznaje i slobodnim položajem u rečenici, pisanjem dijakritičkih znakova - zareza i uskličnika, a prozodijski je markiran intonacijom ili, primjerice, čelnim ${ }^{1}$ naglaskom (Karlić i Cvitković, 2017, str. 231).

U svim fleksijskim jezicima vokativ se ne realizira specifičnim gramatičkim morfemom, stoga u hrvatskome jeziku vokativ predstavlja nestabilnu morfološku kategoriju i djelomično je gramatikaliziran (Karlić i Cvitković, 2017, str. 229, 240). Naime, niveliraju se nominativna i vokativna morfološka obilježja (Rišner, 2006, str. 131), što se definira kao gramatička homonimija, istoobličnost ili sinkretizam (Jelaska, 2006, str. 42), a rezultat je to međudjelovanja inojezičnih dodira, organskih idioma, razgovornoga i administrativnoga diskursa (Težak, 1982, str. 35; Badurina, 2010, str. 4) i načela jezične ekonomije čime, uz interpunkcijske i paralingvističke znakove, obilježenost vokativa posebnim gramatičkim morfemom postaje zalihosna značajka s obzirom na njegove komunikacijske funkcije (Karlić i Okuka, 2015, str. 83). Zato je u kontekstu inherentne povezanosti vokativa s komunikacijskim kontekstom (Badurina, 2010, str. 6) primjerenije govoriti o njegovoj demorfologizaciji (Trovesi, 2008, str. 28) nego izumiranju.

U rečeničnoj strukturi vokativna je pozicija slobodna, što znači da vokativ može stajati na početku rečenice, gdje se najbolje ističe njegova apelativna uloga, te u sredini ili na kraju rečenice, gdje apelativnost slabi, no naglašena je emfatičnost (Vlastelić, 2013, str. 303). Vokativni se izraz tvori kao monolektički model (antroponim, apelativ, pridjev, osobna zamjenica, zbirna imenica) ili sintagmatski model (zavisnosložena sintagma supstantiva i njezina zavisna člana atributa ili apozicije) (Babić, 2010, str. 326-327), a vokativnim se likovima često pridružuju apelativni usklici, čija je svrha isticanje određenih vokativnih komunikacijskih uloga (Daniel i Spencer, 2009, str. 626). Sintaktičnost vokativnoga izraza ostvaruje se s obzirom na autosintaktičnost ili asintaktičnost: vokativ je autosintaktičan kada je realiziran u vidu samostalne rečenice, a asintaktičan kada je dio rečenične strukture (Babić, 2010, str. 326), pri čemu njegov položaj nije motiviran glagolom kao rečeničnim ishodištem, stoga vokativ ostaje kao izvanjski pridruženi član rečeničnog ustrojstva (Ljubibratić, 1987, str. 67). U tome ga se svjetlu može motriti kao samostalnu rečenicu (Marković, 2013, str. 256), odjelitu sintagmatsku/sintaktičku konstrukciju (Ljubibratić,

1 „Morfološki se uvjetovan silazni naglasak zove čelni naglasak. Čelni naglasak nije svaki naglasak na čelu riječi niti svaki naglasak silazne intonacije, već samo onaj silazni naglasak koji u određenim riječima i oblicima riječi dolazi u prvom slogu izgovorne cjeline ili naglasnice kao njihova morfološka oznaka. Čelni je naglasak karakterističan za npr. kategoriju vokativa, aorista, pridjeva radnog i trpnog“" (Barić i sur., 2005, str. 93). Primjerice, jùnāk > jünāče, vòda $>$ vödō. 
1987, str. 67; Skljarov, 1962, str. 409) ili posebnu vrstu rečenice, odnosno surečenice (Pranjković, 1987, str. 78).

Na semantičko-pragmatičkoj razini vokativ se može odrediti kao polisemičan oblik ili izraz, čime, pored konativne funkcije usmjerene na primatelja poruke, implicira emotivnu, fatičku ili poetsku funkciju (Glušac i Mikić Čolić, 2017, str. 452). Svojstveno razlikovno obilježje kategorije vokativnosti njezina je komunikacijska funkcija (Badurina, 2010, str. 7), stoga se među vokativnim komunikacijskim ulogama mogu razabrati obraćanje, dozivanje, oslovljavanje, skretanje pozornosti primatelju poruke na njezin određeni dio, ispitivanje obavijesnoga tijeka u komunikacijskome kanalu, invokacija i modalna funkcija (Ljubibratić, 1987, str. 70-71; Stolac, 2005, str. 178).

Cilj je ovoga rada na korpusu aktualnih udžbenika hrvatskoga jezika za osnovnu i srednju školu, odabranih prema Konačnom rezultatu odabira udžbenika iz „,Kataloga odobrenih udžbenika u školskoj godini 2020./2021. - osnovne škole“ i Konačnom rezultatu odabira udžbenika iz „Kataloga odobrenih udžbenika u školskoj godini 2020./2021. - srednje škole", te četirima suvremenim školskim gramatikama hrvatskoga jezika, Gramatici hrvatskoga jezika za gimnazije i visoka učilišta (2007) Josipa Silića i Ive Pranjkovića, Gramatici hrvatskoga jezika: priručnika za osnovno jezično obrazovanje (2016) Stjepka Težaka i Stjepana Babića, Školskoj gramatici hrvatskoga jezika (2017) Sande Ham i Hrvatskoj školskoj gramatici (2019) Lane Hudeček i Milice Mihaljević, analizirati poimanje vokativa i kategorije vokativnosti u okviru nastavnoga predmeta Hrvatski jezik s obzirom na fonetička, fonološka, morfološka, sintaktička, pravopisna i pragmatičko-semantička vokativna obilježja. Polazišna je pretpostavka da je poučavanje vokativa i o vokativu usmjereno na formalno-gramatičku komponentu čime se pruža nepotpuna slika položaja i uloge vokativa u hrvatskome jeziku. Stoga namjera je rada pružiti smjernice za sveobuhvatan pristup poučavanja vokativnih obilježja koji uključuje sjedinjavanje tradicionalne gramatičke i suvremene komunikacijsko-funkcionalne paradigme. ${ }^{2}$

\section{METODOLOGIJA}

Vremenski okvir odabranoga korpusa odnosi se na suvremene udžbenike nastavnoga predmeta Hrvatski jezik za osnovne i srednje škole te četiri školske gramatike hrvatskoga jezika. Kriterij odabira udžbenika za analizu obrade vokativnih obilježja određen je prema Konačnom rezultatu odabira udžbenika iz „,Kataloga odobrenih udžbenika u školskoj godini 2020./2021. - osnovne

2 „Jezik, smatraju formalni lingvisti, valja opisati nezavisno od njegove uporabe u komunikaciji, a temeljni je zadatak lingvista opisati model jezične sposobnosti, a ne jezične izvedbe (Chomsky 1965: 4). (...) Funkcionalni pristupi, za razliku od formalnih, u žarište stavljaju komunikaciju kao jednu od najvažnijih funkcija jezika u društvu, a značenje pri tome igra veliku ulogu“ (Borucinsky i Tominac Coslovich, 2015, str. 12-13). 
škole“ i Konačnom rezultatu odabira udžbenika iz „,Kataloga odobrenih udžbenika u školskoj godini 2020./2021. - srednje škole", a s obzirom na nastavni sadržaj koji se odnosi na poučavanje vokativa, odnosno odgojno-obrazovne ishode OŠ HJ A.5.5. ${ }^{3}$ i SS̆ HJ A.3.5. ${ }^{4}$ unutar predmetnoga područja hrvatski jezik i komunikacija iz Odluke o donošenju kurikuluma za nastavni predmet Hrvatski jezik za osnovne škole i gimnazije u Republici Hrvatskoj (NN 10/2019), tj. Kurikuluma nastavnog predmeta Hrvatski jezik za osnovne škole $i$ gimnazije (2019) eksperimentalnoga programa Škola za život te odgojno-obrazovni ishod SŠ HJ A.3.5. ${ }^{5}$ unutar predmetnoga područja hrvatski jezik i komunikacija iz Odluke o donošenju kurikuluma za nastavni predmet Hrvatski jezik za srednje strukovne škole na razini 4.2. u Republici Hrvatskoj (NN 10/2019), tj. Kurikuluma nastavnog predmeta Hrvatski jezik za srednje strukovne škole na razini 4.2. (2019) eksperimentalnoga programa Škola za život, promotreni su osnovnoškolski udžbenici za peti razred i srednjoškolski udžbenici za treći razred gimnazije i/ili strukovnih škola.

Korpus osnovnoškolskih udžbenika obuhvaća šest udžbenika od kojih je jedan integrirani: Hrvatski za 5: udžbenik iz hrvatskoga jezika za peti razred osnovne škole (Družijanić-Hajdarević i sur., 2020), Hrvatska krijesnica 5: udžbenik iz hrvatskoga jezika za 5. razred osnovne škole (Kovač i Jukić, 2019), Hrvatski bez granica 5: integrirani udžbenik hrvatskoga jezika i književnosti za peti razred osnovne škole (Levak i sur., 2020), Hrvatske jezične niti 5: udžbenik iz hrvatskoga jezika za peti razred osnovne škole (Miloloža i sur., 2020), Volim hrvatski 5: udžbenik hrvatskoga jezika u petome razredu osnovne škole (Rihtarić i sur., 2020) i Naš hrvatski 5: udžbenik hrvatskoga jezika u petome razredu osnovne škole (Šojat, 2020).

Korpus srednjoškolskih udžbenika obuhvaća pet udžbenika od kojih su tri integrirana: Fon-Fon 3: udžbenik hrvatskoga jezika za treći razred gimnazije i srednjih strukovnih škola (Dujmović Markusi i Španjić, 2020), Putokazi 3: udžbenik za hrvatski jezik, književnost i komunikacijske vještine 21. stoljeća za 3. razred strukovnih škola na razini 4.2 i gimnazije (Marčan i Grubišić Belina, 2020), Hrvatski jezik i književnost 3: integrirani udžbenik hrvatskoga jezika za treći razred gimnazije (Serdarević i sur., 2020), Biram knjigu i riječ 3: čitanka $i$ udžbenik iz hrvatskoga jezika za treći razred strukovnih škola (Zrinjan, 2020a)

3 „Učenik oblikuje tekst i primjenjuje znanja o promjenjivim i nepromjenjivim riječima na oglednim i čestim primjerima“" (Odluka o donošenju kurikuluma za nastavni predmet Hrvatski jezik za osnovne škole i gimnazije u Republici Hrvatskoj, NN 10/2019).

4 „Učenik analizira morfološka obilježja riječi i primjenjuje znanja pri oblikovanju teksta“ (Odluka o donošenju kurikuluma za nastavni predmet Hrvatski jezik za osnovne škole i gimnazije u Republici Hrvatskoj, NN 10/2019).

5 „Učenik analizira morfološka obilježja riječi i primjenjuje znanja pri oblikovanju teksta“ (Odluka o donošenju kurikuluma za nastavni predmet Hrvatski jezik za srednje strukovne škole na razini 4.2. u Republici Hrvatskoj, NN 10/2019). 
i Lica riječi 3: udžbenik iz hrvatskog jezika za treći razred gimnazija i četverogodišnjih strukovnih škola (Zrinjan, 2020b). S obzirom na to da su udžbenici Biram knjigu i riječ 3 i Lica riječi 3 iste autorice, a prvi je integrirani udžbenik za strukovne škole s istim sažetijim nastavnim sadržajem te drugi za gimnazije i četverogodišnje strukovne škole s istim proširenijim sadržajem, u analizi će se zbog praktičnosti navoditi primjeri iz udžbenika Lica riječi 3.

Vremenski korpus školskih gramatika odnosi se na posljednja izdanja objavljena u 21. stoljeću, a to su Gramatika hrvatskoga jezika za gimnazije i visoka učilišta (Silić i Pranjković, 2007), Gramatika hrvatskoga jezika: priručnik za osnovno jezično obrazovanje (Težak i Babić, 2016), Školska gramatika hrvatskoga jezika (Ham, 2017) i Hrvatska školska gramatika (Hudeček i Mihaljević, 2019). Silićeva i Pranjkovićeva Gramatika hrvatskoga jezika za gimnazije i visoka učilišta (2007), prvotno objavljena 2005. godine, sastavljena je od četiriju dijelova: Fonologija, Morfologija, Sintaksa i Funkcionalni stilovi hrvatskoga standardnog jezika, što je prvi put da se u kontekstu gramatičkoga opisa pristupa s razine funkcionalnih stilova izmičući očekivanjima tradicionalne obrade gramatičke građe (Hudeček, 2007, str. 380). Budući da se sve jezične razine međusobno prožimaju, ova je gramatika uspjela udovoljiti dvama ciljevima - opisati fonološke pojave kako bi se objasnile one na polju morfologije te produbiti sintaktička poimanja analizom na razini teksta (Matešić, 2006, str. 142). U ovome se radu obrađuje drugo izdanje ove gramatike iz 2007. godine. Težakova i Babićeva gramatika prvi je put objavljena 1966. godine čime predstavlja najdugovječniju i najizdavaniju školsku gramatiku hrvatskoga jezi$\mathrm{ka}$, stoga se u ovome radu promatra njezino najaktualnije, osamnaesto izdanje. Gramatika Sande Ham Školska gramatika hrvatskoga jezika s prvim izdanjem iz 2002. godine predstavlja prvu gramatiku hrvatskoga jezika u razdoblju dvadeset i prvoga stoljeća. Premda namijenjena za osnovnoškolsku upotrebu prateći program učenja i poučavanja nastavnoga predmeta Hrvatski jezik u osnovnim školama, njezina se svrhovitost proteže i na primjenu u srednjim školama. Osobitost ove gramatike ogleda se u koncepciji izlaganja gramatičkoga sadržaja tako da su naslovi formulirani pitanjima na koja se odgovor dobiva u nastavku teksta. Budući da je riječ o gramatici predviđenoj za školsku upotrebu, ova je gramatika napametna i normativna s tendencijom izlaganja jezičnih savjeta odlikujući se pritom jednostavnošću i konciznošću (Ham, 2006, str. 240). U ovome se radu promatra peto, izmijenjeno izdanje iz 2017. godine. Najnovije ostvarenje u području školskih gramatika jest Hrvatska školska gramatika autorica Lane Hudeček i Milice Mihaljević, a ovim je radom obuhvaćeno njezino drugo izdanje iz 2019. godine.

Vidljivo je kako je odabrana građa za raščlambu vokativne problematike usmjerena na aktualne udžbenike u tekućoj školskoj godini (2020./2021.), kao i posljednje publikacije u području školskih gramatika, čime se nastoji uvidjeti trenutačnu razinu postojanosti tradicionalnih, odnosno utjecaja suvremenih 
teorijskih fluktuacija u obrazovni sustav u kontekstu obrade nastavnoga sadržaja vezanoga za vokativ i kategoriju vokativnosti uopće. U navedenome se korpusu vokativ promatra s obzirom na zastupljenost obrade fonetskih, fonoloških, morfoloških, sintaktičkih, pravopisnih i pragmatičko-semantičkih obilježja, odnosno sjedinjavanjem tradicionalne i suvremene jezikoslovne paradigme. Pod fonetskim se vokativnim obilježjima podrazumijeva zastupljenost njegovih naglasnih, tj. izgovornih specifičnosti. Fonološka obilježja obuhvaćaju glasovne promjene vokativnih oblika zabilježene u navedenome korpusu. Morfološka obilježja podrazumijevaju posebnosti distribucije vokativnih gramatičkih morfema i ostalih oblikotvornih značajka. Sintaktička se obilježja promatraju s obzirom na karakteristike vokativnoga izraza i položaja vokativa u rečeničnoj strukturi u odnosu na ostale članove rečeničnoga ustrojstva. Pravopisna obilježja predmnijevaju pravila pisanja zareza u vidu vokativnoga oblika ili vokativnoga izraza, a analizom semantičko-pragmatičkih obilježja zadire se u područje kategorije vokativnosti, odnosno razine prepoznavanja i definiranja vokativnih komunikacijskih funkcija, čime se promatra afirmiranost suvremene funkcionalne jezikoslovne paradigme koja se usmjerava na padežne uloge i značenja. Usto, u udžbeničkome i gramatičkome korpusu analizira se poimanje pojma padeža, kao i redoslijeda poučavanja padeža u osnovnoj školi kako bi se promotrila načela poučavanja vokativa, a u analizi je srednjoškolskih udžbenika polazište poučavanje o vokativu, čime se pretpostavlja razvoj i proširenje određenja vokativnih obilježja u odnosu na osnovnu školu.

Cjelokupna je analiza rezultata podijeljena na dva dijela sa zasebnom raščlambom osnovnoškolskih i srednjoškolskih udžbenika, pri čemu se rezultati dobiveni u osnovnoškolskim udžbenicima uspoređuju s onima u Gramatici hrvatskoga jezika: priručniku za osnovno jezično obrazovanje (2016) i Školskoj gramatici hrvatskoga jezika (2017), a oni dobiveni u srednjoškolskim udžbenicima s Gramatikom hrvatskoga jezika za gimnazije i visoka učilišta (2007) i Hrvatskom školskom gramatikom (2019). Važno je napomenuti kako je analiza udžbenika usmjerena prema njihovoj interpretaciji na znanstveno-teorijskoj, a ne metodičkoj ili praktičnoj razini, imajući na umu načelo znanstvenosti i načelo primjerenosti nastave hrvatskoga jezika (v. Težak, 1996) s ciljem ustvrđivanja interpretacije vokativnih obilježja u njima. 
Tablica 1. Kratice koje se pojavljuju u radu

\begin{tabular}{|c|c|}
\hline Kratica & Udžbenik \\
\hline FF & $\begin{array}{l}\text { Fon-Fon 3: udžbenik hrvatskoga jezika za treći razred gimnazije } i \\
\text { srednjih strukovnih škola }\end{array}$ \\
\hline HBG & $\begin{array}{l}\text { Hrvatski bez granica 5: integrirani udžbenik hrvatskoga jezika i } \\
\text { književnosti za peti razred osnovne škole }\end{array}$ \\
\hline HJK & $\begin{array}{l}\text { Hrvatski jezik i književnost 3: integrirani udžbenik hrvatskoga } \\
\text { jezika za treći razred gimnazije }\end{array}$ \\
\hline HJN & $\begin{array}{l}\text { Hrvatske jezične niti 5: udžbenik iz hrvatskoga jezika za peti razred } \\
\text { osnovne škole }\end{array}$ \\
\hline HK & $\begin{array}{l}\text { Hrvatska krijesnica 5: udžbenik iz hrvatskoga jezika za 5. razred } \\
\text { osnovne škole }\end{array}$ \\
\hline HZ5 & $\begin{array}{l}\text { Hrvatski za 5: udžbenik iz hrvatskoga jezika za peti razred osnovne } \\
\text { škole }\end{array}$ \\
\hline LR & $\begin{array}{l}\text { Lica riječi 3: udžbenik iz hrvatskog jezika za treći razred gimnazija } \\
\text { i četverogodišnjih strukovnih škola }\end{array}$ \\
\hline NH & $\begin{array}{l}\text { Naš hrvatski 5: udžbenik hrvatskoga jezika u petome razredu } \\
\text { osnovne škole }\end{array}$ \\
\hline $\mathbf{P}$ & $\begin{array}{l}\text { Putokazi 3: udžbenik za hrvatski jezik, književnost i komunikacijske } \\
\text { vještine 21. stoljeća za 3. razred strukovnih škola na razini } 4.2 i \\
\text { gimnazije }\end{array}$ \\
\hline VH & $\begin{array}{l}\text { Volim hrvatski 5: udžbenik hrvatskoga jezika u petome razredu } \\
\text { osnovne škole }\end{array}$ \\
\hline
\end{tabular}

\section{REZULTATI I RASPRAVA}

\section{OSNOVNOŠKOLSKI UDŽBENICI I ŠKOLSKE GRAMATIKE (TEŽAK I BABIĆ, 2016; HAM, 2017)}

Prema Odluci o donošenju kurikuluma za nastavni predmet Hrvatski jezik za osnovne škole i gimnazije u Republici Hrvatskoj (NN 10/2019), tj. Kurikuluma nastavnog predmeta Hrvatski jezik za osnovne škole i gimnazije (2019) eksperimentalnoga programa Škola za život, prijedlog razrade odgojno-obrazovnoga ishoda OŠ HJ A5.5. u vidu obrade padeža u petome razredu osnovne škole odnosi se na razlikovanje morfoloških kategorija kojima se uspostavljaju veze među riječima, što pored padeža uključuje rod, broj, lice i vrijeme, te uočavanje padeža kao različitih oblika iste riječi na čestim i oglednim primjerima. Ovi ishodi prate tradicionalnu hrvatsku gramatikološku misao koja padež određuje kao gramatičku kategoriju, tj. morfološku značajku imenica, uz rod i broj, definirajući ga kao „morfološku kategoriju koja izriče različite odnose onoga što riječ znači prema sadržaju rečenice (Barić i sur., 2005, str. 101)“, odnosno u vidu gramatičkih funkcija i sintaktičkih odnosa (Babić i sur., 2007, str. 304) ili pak kao „oblik riječi koji je ovisan o njezinoj službi i odnosu prema drugim 
riječima u rečenici“ (Težak i Babić, 1996, str. 81). Međutim, u novije se vrijeme vode polemike je li određenje padeža na morfološkoj i sintaktičkoj, odnosno, gramatičkoj razini cjelovito ili je potrebno padež promatrati i sa semantičkoga aspekta kao „koherentnu semantičko-gramatičku kategoriju“ označenu općim značenjem i njegovim konkretnim realizacijama u određenim komunikacijskim situacijama (Belaj i Tanacković Faletar, 2014, str. 230) te, s druge strane, kao „semantičko-sintaktičku kategoriju, koja se može i ne mora realizirati morfološki“ (Marković, 2013, str. 246). S obzirom na ishode, očekuje se kako će i obrada vokativa u osnovnoškolskim udžbenicima u većoj mjeri biti usmjerena na njegova morfološka i sintaktička, pa čak i pravopisna (pisanje zareza i uskličnika) te fonološka obilježja (glasovne promjene), nego njegove inherenthe komunikacijske specifičnosti.

U promatranim se udžbenicima padež redom definira kao različit oblik iste imenice (HBZ, str. 11; HJZ, str. 32; HK, str. 51; HZ5, str. 98; NZ, str. 33; VH, str. 39), a padežna se paradigma čak poistovjećuje s tablicom množenja koju treba naučiti i ponavljati (NH, str. 32), čime se svodi i što rezultira apstraktnim formalno-pojmovnim pristupom i pasivnim usvajanjem, odnosno jezičnom reprodukcijom (nasuprot jezičnomu stvaralaštvu) nastavnoga sadržaja koji je temelj daljnjega usvajanja hrvatskoga jezika na svim razinama, tj. ciklusima obrazovanja. Ham (2017, str. 39) u svojoj Školskoj gramatici hrvatskoga jezika padež definira u svjetlu izricanja odnosa imenica s ostalim riječima u rečenici, stoga imenica promjenom padeža mijenja svoj odnos prema drugim riječima. Slično određenje nude Težak i Babić (2016, str. 95) u Gramatici hrvatskoga jezika: priručniku za osnovno jezično obrazovanje konstatirajući da padež predstavlja oblik određene riječi koji je ovisan o službi te riječi i njezinu odnosu prema drugim riječima u rečenici. Dakle, školske gramatike dotiču se relacija među riječima, a ne samo promjene njihovih oblika kako smo vidjeli da je naznačeno u svim osnovnoškolskim udžbenicima.

Određivanje padeža te njihovo osvještavanje u vidu primjene koja je u skladu sa standardnojezičnom normom smatra se jednim od najkompleksnijih područja gramatike odnosno pragmatike hrvatskoga jezika (Jelaska, 2006, str. 40-41). U ovome se kontekstu na prvi pogled mogu uočiti različite osnovnoškolske udžbeničke paradigme rasporeda padeža tijekom njihova poučavanja i vokativnoga mjesta u tomu sustavu: 
Tablica 2. Redoslijed poučavanja padeža u osnovnoškolskim udžbenicima hrvatskoga jezika

\begin{tabular}{lll}
\hline Udžbenik & Redoslijed poučavanja padeža $^{6}$ & $\begin{array}{l}\text { Pozicija vokativa pri } \\
\text { poučavanju padeža }\end{array}$ \\
\hline $\mathrm{HBZ}^{7}$ & $\mathrm{~N}, \mathrm{~A}, \mathrm{G}, \mathrm{D}$ i L, I, V & sedmi padež \\
$\mathrm{HJN}^{8}$ & $\mathrm{~N}, \mathrm{~A}, \mathrm{G}, \mathrm{D}$ i L, I, V & sedmi padež \\
$\mathrm{HK}^{9}$ & $\mathrm{~N}$ i V, A i G, D i L, I & zajedno s N (drugi padež) \\
$\mathrm{HZ5}^{10}$ & $\mathrm{~N}, \mathrm{~A}, \mathrm{G}, \mathrm{D}$ i L, I, V & sedmi padež \\
$\mathrm{NH}^{11}$ & $\mathrm{~N}$ i A, G, D i L, V, I & sesti padež \\
$\mathrm{VH}^{12}$ & $\mathrm{~N}, \mathrm{G}, \mathrm{D}, \mathrm{A}, \mathbf{V}, \mathrm{L}, \mathrm{I}$ & peti padež \\
\hline
\end{tabular}

Iz Tablice 2. razvidno je kako se vokativ u jednome udžbeniku poučava zajedno s nominativom, točnije kao drugi padež, potom u jednome udžbeniku tradicionalno kao peti padež, u jednome udžbeniku kao šesti padež i u trima udžbenicima kao posljednji, sedmi padež, što dovodi do triju zaključaka: redoslijed poučavanja svih padeža, pa tako i vokativa, nije usuglašen, ${ }^{13}$ prevladava poučavanje vokativa kao posljednjega padeža i vokativ se najčešće obrađuje samostalno. Obrada vokativa na kraju padežnoga ciklusa može se objasniti činjenicom da se vokativ ne vezuje za karakteristična padežna pitanja i zato što je samostalan u odnosu na ostale članove rečeničnoga ustrojstva. Poučavanje vokativa kao posljednjega padeža prema navedenim kriterijima implicira orijentiranost prema morfološkim i sintaktičkim, to jest njegovim gramatičkim odrednicama. No pri tome ne se smije zanemariti i kriterij učestalosti upotrebe padeža, stoga valja napomenuti kako prema istraživanju zastupljenosti padeža u govorenim i pisanim tekstovima vokativ predstavlja padež koji se primjetno najmanje upotrebljava unutar obaju diskursa (Bičanić, 2009, str. 39; Kolaković, 2007, str. 268).

Za podrobnije tumačenje valja promotriti koji su aspekti vokativnih obilježja zaista prisutni u osnovnoškolskim udžbenicima prilikom poučavanja vokativa. Što se tiče njegovih fonoloških obilježja, u svim je promotrenim udžbenicima zabilježena promjena glasova u oblicima vokativa jednine imenica

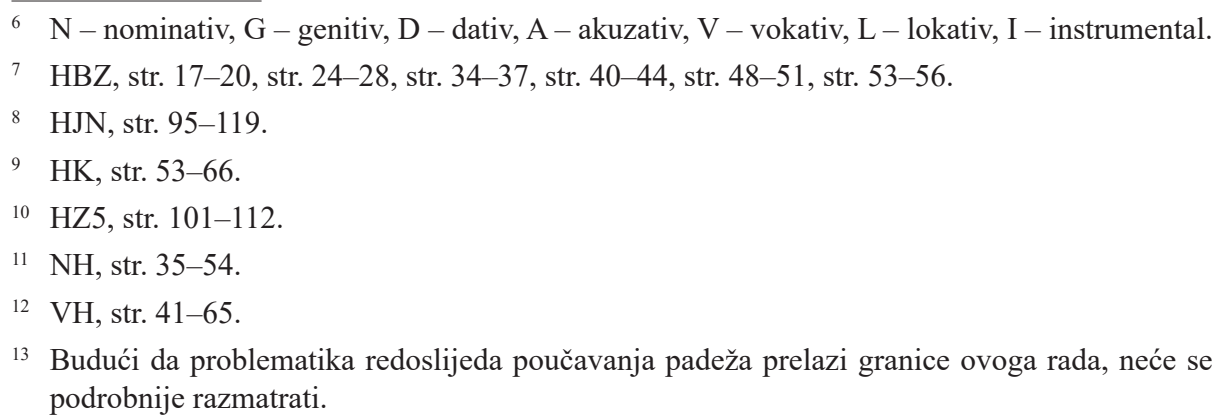


muškoga roda, međutim s različitim brojem glasova u promjeni: tri udžbenika bilježe promjenu glasova $k, g$ i $h$ ispred gramatičkoga morfema -e u glasove $\check{c}$, $\check{s}$ i $\check{z}$ (putnik > putniče, drug > druže, duh > duše) (HBZ, str. 55; HJN, str. 117; HK, str. 55), dva udžbenika istim glasovima u promjeni dodaju i glas $c$ koji se mijenja u glas $\check{c}$ (starac > starče) (NH, str. 47; VH5, str. 56), a u jednomu je udžbeniku uz glasove $c, k, g$, i $h$ pridružen glas $z$ koji se mijenja u glas $\check{z}$ (vitez $>$ viteže) (HZ5, str. 112). U jednome od šest udžbenika primijećena je i promjena glasova $k, g$, i $h$ u glasove $c, z$ i $s$, tj. sibilarizacija za vokativ množine imenica muškoga roda a-sklonidbe (vrag > vrazi, duh > dusi) (HJN, str. 117). Isti udžbenik navodi i glasovnu promjenu nepostojanoga $a$ za određene množinske vokativne oblike imenica muškoga roda a-sklonidbe (momak > momče, momci) (HJN, str. 117) koja u ostalih pet udžbenika nije uočena. Zanimljivo je kako se fonološka odrednica, tj. glasovne promjene u Školskoj gramatici određuju kao padežno razlikovno sredstvo (Ham, 2017, str. 40-41). Tako Ham (2017, str. 47) u svjetlu vokativa navodi promjenu palatalizacije navodeći sve glasove $(c, k, g, h \mathrm{i} z)$ koji ulaze u promjenu u vokativu jednine imenica muškoga roda a-sklonidbe, kao i glasovnu promjenu sibilarizacije za množinske oblike. Iste su glasovne promjene zabilježene u Težakovoj i Babićevoj gramatici (2016, str. 65). Razvidno je kako samo jedan udžbenik (HJN) slijedi cjelovito određenje glasovnih promjena u jedninskim i množinskim vokativnim oblicima - nepostojano $a$, sibilarizaciju i palatalizaciju s time da su potonje prisutne i u dvjema analiziranim školskim gramatikama, no u ostalih pet udžbenika glasovi koji se pojavljuju u palatalizaciji reducirani su, najčešće na $k, g$ i $h$, što rezultira manjom usmjerenosti na vokativna fonološka obilježja, čemu se pridružuje i izostavljanje ostalih glasovnih promjena (nepostojanoga $a$ i sibilarizacije), što se razabire iz Tablice 3.

Tablica 3. Fonološka vokativna obilježja u osnovnoškolskim udžbenicima

\begin{tabular}{lll}
\hline Udžbenik & Glasovna promjena & $\begin{array}{l}\text { Razrada glasovne promjene } \\
\text { palatalizacije }\end{array}$ \\
\hline HBZ & palatalizacija & $k, g, h>\check{c}, \check{z}, \check{s}$ \\
HJN & $\begin{array}{l}\text { nepostojano } a \\
\text { palatalizacija } \\
\text { sibilarizacija }\end{array}$ & $k, g, h>\check{c}, \check{z}, \check{s}$ \\
HK & palatalizacija & $k, g, h>\check{c}, \check{z}, \check{s}$ \\
HZ5 & palatalizacija & $c$ i $k, g$ i $z, h>\check{c}, \check{z}, \check{s}$ \\
NH & palatalizacija & $c$ i $k, g, h>\check{c}, \check{z}, \check{s}$ \\
VH & palatalizacija & $c$ i $k, g, h>\check{c}, \check{z}, \check{s}$ \\
\hline
\end{tabular}

Promjena intonacije pri izgovoru vokativnih oblika u udžbenicima nije navedena, čak ni u udžbeniku koji je predvidio obrađivanje vokativa zajedno s nominativom (HK). U tom se slučaju udžbenici osvrću na istoobličnost pojedinih 
nominativnih i vokativnih oblika (HK, str. 55; NH, str. 48), čak i razlikovanje njihovih značenja (HBZ, str. 55; HJN, str. 117; HK, str. 55), no ne ističući zasebno i njihovu izgovornu raznolikost. ${ }^{14}$ Iz navedenoga dade se zaključiti kako su udžbenici prvotno usmjereni na vokativna fonološka obilježja koja utječu na promjenu oblika, točnije morfološka svojstva i to ponajviše na palatalizaciju u jedninskim oblicima, a njegove se fonetske, odnosno izgovorne značajke ne smatraju vrijednima posebnoga isticanja iako predstavljaju jednu od specifičnosti vokativnih obilježja, poglavito u vidu karakterističnoga čelnog naglaska.

Registrirane vokativne oblikotvorne karakteristike odnose se na već gore navedeni sinkretizam nominativnih i vokativnih oblika (HK, str. 55; NH, str. 48), alternaciju gramatičkih morfema -e i -u u imenica muškoga roda koje završavaju dočetcima -ar i -ir (ribar > ribare/ribaru; pastir > pastire/pastiru) u dvama udžbenicima (HK, str. 56; NH, str. 47), realizaciju vokativnoga gramatičkog morfema -u za imenice muškoga roda koje završavaju nepčanikom također u dvama udžbenicima ( rijatelj $>$ prijatelju, puž > pužu, Zorić > Zoriću) (HZ5, str. 112; NH, str. 47), razlikovanje sklonidbe prezimena muških i ženskih osoba (Matija Matiću! Matija Matić!) u jednome udžbeniku (HZ5, str. 112), specifičnost vokativnih gramatičkih morfema za određena osobna imena (Maja > Majo, Goran > Gorane), ali i njihova izjednačenost s nominativnima (Mama! Tata! Hrvatska!) u jednome udžbeniku (NH, str. 48) te naposljetku tvorba vokativnih oblika osnovom i gramatičkim morfemom s obzirom na imeničke rodove, odnosno distribucija vokativnih gramatičkih morfema u dvama udžbenicima (HJN, str. 116-117; NH, str. 47).

Tablica 4. Morfološka vokativna obilježja u osnovnoškolskim udžbenicima

\begin{tabular}{|c|c|c|c|c|c|c|}
\hline \multirow{2}{*}{ Morfološko obilježje } & \multicolumn{6}{|c|}{ Udžbenik } \\
\hline & HBZ & HJN & HK & HZ5 & NH & VH \\
\hline $\mathrm{N}=\mathrm{V}$ & & & + & & + & \\
\hline $\mathrm{N}$ jd. -ar, -er $>\mathrm{V}$ jd. -e/-u & & & + & & + & \\
\hline osnova na nepčanik > V jd. -e & & & & + & + & \\
\hline osnova na nenepčanik $>$ Vjd. -u & & & & + & + & \\
\hline prezimena $\mathrm{u} \mathrm{V}$ & & + & & & & \\
\hline imena u V & & & & & + & \\
\hline $\begin{array}{l}\text { raspodjela gram. morfema s obzirom na } \\
\text { rod imenice }\end{array}$ & & + & & & + & \\
\hline
\end{tabular}

Iz priloženoga se u Tablici 4., a posebno posljednje kategorije raspodjele gramatičkih morfema s obzirom na muški, ženski i srednji rod, može uočiti čvrsta ukorijenjenost vokativne morfološke odrednice čime se naglašava specifičnost

14 Koristi se pojmovima intonacija te izgovor jer se nastavni sadržaj o naglascima u osnovnoj školi obrađuje kasnije, u sedmome razredu osnovne škole. 
vokativnih gramatičkih morfema, a time i pravilna upotreba vokativnih oblika, kao i njihova gramatička homonimija s nominativnima u određenim slučajevima. Međutim, nije moguće odrediti koja je ili koje su od njih najzastupljenije, kao što je to bilo u slučaju fonoloških obilježja, tj. glasovnih promjena, što govori o različitom poimanju važnosti isticanja pojedinih vokativnih morfoloških obilježja. S obzirom na tendenciju demorfologizacije vokativa u hrvatskome jeziku, poglavito u svakodnevnoj komunikaciji u kojoj se zbiva okamenjivanje nominativnih gramatičkih morfema za vokativne oblike, a time i promjena padežnih funkcija (Kodrić Gagro i Vraneša, 2016, str. 403) i obraćanje kao primarnu funkciju vokativa, više bi pozornosti trebalo posvetiti oblikovanju vokativnih likova za vlastita imena, odnosno antroponime. Vidljivo je kako su u jednome od šest udžbenika (NH) prisutne gotovo sve navedene kategorije oblikotvornih vokativnih značajka, pri čemu se u tomu udžbeniku ogleda najviša zastupljenost morfološke vokativne odrednice. Također, valja napomenuti, jer je iznimno indikativno, kako u dvama udžbenicima (HBZ i VH) nije uopće uočeno isticanje pojedinih pravila raspodjele vokativnih gramatičkih morfema, čime se naslućuje njihova veća usmjerenost prema sintaktičkim i/ili komunikacijskim vokativnim obilježjima nasuprot ostalim udžbenicima, što će se detaljnije promotriti u nastavku.

Nadalje, od vokativnih oblikotvornih značajka, Ham (2017, str. 46-47) u Školskoj gramatici naglašava razliku distribucije vokativnih jedninskih gramatičkih morfema -e i -u za imenice muškoga roda koje u nominativu jednine završavaju ništičnim gramatičkim morfemom, a čija osnova završava nepčanikom odnosno nenepčanikom. Težak i Babić (2016, str. 100) nude detaljniju razradu raspodjele gramatičkoga morfema -u i to za imenice na -ic (konjicu), -č(a)c (Otočcu), -č(a)k (mačku), -ć(a)k (mućku), -d(a)k (pretku), -dž(a)k (kovrčku), -đ(a)k (omećku), -t(a)k (patku), -z(a)g (bazgu, mozgu < mozak), etnike i toponime na -ez (Englezu), -iz (Parizu) i -uz (Francuzu), imenice na -k, -g, -h i -c preuzete iz drugih jezika (blicu, tenku, ergu, cehu). Ham (2017, str. 47) bilježi alternaciju gramatičkih morfema -e i -u za imenice muškoga roda koje u nominativu jednine završavaju na -ar (gospodar > gospodare i gospodaru), a Težak i Babić (2016, str. 101) uz dvojne gramatičke morfeme za imenice na -ar dodaju i one koje završavaju na -er (djevere, djeveru) te -ir (leptire, leptiru). Istoobličnost nominativnih i vokativnih oblika u Školskoj je gramatici navedena za muška imena koja završavaju gramatičkim morfemima -e i -o (Ham, 2017, str. 47), a u Gramatici se hrvatskoga jezika spominje u kontekstu zapovjednih (Vod, stoj!) i dozivnih tipova (Konobar, platio bih!) te vlastitih imena stranoga podrijetla (Dođi, stari Fritz) (Težak i Babić, 2016, str. 101). $\mathrm{Za}$ imenice ženskoga roda Ham (2017, str. 51) navodi pojavu jedninskih gramatičkih morfema -a (ženska imena), -e (imenice na -ic-a) i -o (najfrekventniji za apelative ženskoga roda e-sklonidbe), što u detaljnijoj inačici bilježe Težak i Babić (2016, str. 110). Za ženska je imena pretpostavljen nominativni oblik, 
a u vlastitih imena nastalih kraćenjem (Mara, Jela) vokativni je gramatički morfem -o (Ham, 2017, str. 51). Posebnost Školske gramatike iskazana je poglavljem o sklonidbi muških i ženskih vlastitih imena ističući važnost pravilne upotrebe vokativnih oblika te sročnosti imena i prezimena u vokativnome izrazu (Ham, 2017, str. 56-57). Vidljiva je većinska podudarnost Školske gramatike s udžbeničkim rješenjima vokativnih morfoloških obilježja, poglavito s udžbenikom NH u kojemu je primijećen najveći broj zastupljenih vokativnih oblikotvornih specifičnosti, osim o pitanju vokativnih oblika muških i ženskih vlastitih imena koja su u gramatici podrobnije obrađena, a istaknuta samo u dvama udžbenicima (HJN, 117; NH, str. 48). S druge strane, Gramatika hrvatskoga jezika pruža podrobniji prikaz distribucije vokativnih gramatičkih morfema s obzirom na završetak osnove. Problematika sklonidbe vlastitih imena u hrvatskoj gramatikologiji inače nije u potpunosti razriješena jer su znatna kolebanja vokativnih gramatičkih morfema za ženska imena e-sklonidbe zabilježena još u hrvatskim dopreporodnim gramatikama (v. Božanić, 2020, str. 44-45), koja se nastavljaju i u suvremenim gramatikama, pri čemu se u Silićevoj i Pranjkovićevoj gramatici za vlastita ženska imena bilježe dva moguća gramatička morfema -a i -o (Marija/Marijo, Ljiljana/Ljiljano, Božena/ Boženo) (Silić i Pranjković, 2007, str. 109), a u Ham (2017, str. 51) registriran je samo gramatički morfem -a, kao i u Težaka i Babića (2016, str. 110) za osobna imena i prezimena na -a u stilski neobilježenome oslovljavanju te jednome od dvaju udžbenika koji navodi pravilnu upotrebu vokativnih likova ženskih imena e-sklonidbe (HJN, str. 117).

Svi su analizirani udžbenici pozornost posvetili vokativnim sintagmatskim i sintaktičkim značajkama, što je u svim udžbenicima popraćeno i pravopisnim pravilima pisanja zareza kojim se vokativ odvaja od ostatka rečenice i samostalan je u odnosu na ostale članove rečeničnoga ustrojstva, ili kao samostalna rečenica s uskličnikom (HBZ, str. 54; HJN, str. 116; HK, str. 56; HZ5, str. 111; $\mathrm{NH}$, str. 45; VH, str. 43). Nadalje, navodi se kako je vokativni izraz besprijedložan (HJN, str. 116; HZ5, str. 111; NH, str. 47) te se najčešće vezuje za usklike ne odgovarajući tako na padežna pitanja, što je istaknuto u svim udžbenicima (HBZ, str. 56; HJN, str. 116; HK, str. 52; HZ5, str. 110; NH, str. 46; VH, str. 55). Ista se određenja mogu pronaći i u Školskoj gramatici u kojoj je zabilježeno kako vokativ, kao i nominativ, u rečenici ne stoji uz prijedloge te je jedini padež koji ne podržava funkciju rečeničnoga dijela, stoga vokativni izraz nije njezin, a od nje je odijeljen zarezom (Ham, 2017, str. 40, 54, 105). U Gramatici hrvatskoga jezika vokativ je određen kao nezavisan padež koji ne odgovara na pitanja i nije dio rečenice zbog čega se u pismu odvaja zarezom, a istaknuta je i realizacija vokativnoga oblika u službi subjekta pri čemu stoji u funkciji nominativa kako bi se ostvario deseterac u stihovanju (Težak i Babić, 2006, str. 297). U dvama udžbenicima u kojima je prethodno uočena manja razina morfološke usmjerenosti (HBZ i VH) učenike se upućuje i na oblikovanje vokativnoga 
sintagmatskog modela (imenica u vokativu + atribut/apozicija) koji se također odvaja zarezom od ostatka rečenice (HBZ, str. 54; VH, str. 56), što nije opaženo u ostalim udžbenicima i prema tome predstavlja dogradnju vokativnih sintaktičkih i pravopisnih obilježja. Usto u jednome od njih (VH, str. 44) napominje se i slobodna pozicija vokativa u rečenici, točnije da može stajati na njezinu početku, sredini i kraju, čime se dodatno produbljuju spoznaje o odnosima riječi u rečenice, točnije vokativa i ostalih rečeničnih članova. U Tablici 5. primjećuje se kako je, u odnosu na morfološke vokativne značajke, za sintaktička vokativna obilježja primijećena veća podudarnost među osnovnoškolskim udžbenicima, što upućuje na to da su vokativna sintaktička obilježja izuzetno važna odrednica prilikom njegova poučavanja. Također, važnim se čini naglasiti kako je u jednome od udžbenika koji nije posebno izdvajao specifičnosti vokativnih gramatičkih morfema $(\mathrm{VH})$ zabilježeno više sintaktičkih obilježja u odnosu na ostalih pet udžbenika, pri čemu se ističe njegova snažnija usmjerenost na sintaktičku dimenziju vokativa, tj. vokativni izraz.

Tablica 5. Sintaktička vokativna obilježja u osnovnoškolskim udžbenicima

\begin{tabular}{lccccccc}
\hline \multicolumn{1}{c}{ Sintaktičko obilježje } & \multicolumn{7}{c}{ Udžbenik } \\
\cline { 2 - 7 } & HBZ & HJN & HK & HZ5 & NH & VH \\
\hline asintaktičnost & + & + & + & + & + & + \\
autosintaktičnost & + & + & + & + & + & + \\
vokativni izraz besprijedložan & & + & & + & + & \\
ne odgovara na padežna pitanja & + & + & + & + & + & + \\
sintagmatski model vokativnoga & & & & & & \\
izraza & + & & & & & & + \\
pozicija V u rečenici & & & & & & & + \\
\hline
\end{tabular}

U analiziranim udžbenicima valja promotriti i vokativnu semantičko-pragmatičku komponentu za koju se pretpostavlja da će biti najmanje zastupljena u odnosu na prethodne formalno-gramatičke odrednice zbog tradicije hrvatske gramatikološke misli i kurikula nastavnoga predmeta Hrvatski jezik za koji smo ustvrdili da je također tako orijentiran. Vokativne su funkcije u većoj ili manjoj mjeri taksativno izražene u svim udžbenicima. Najčešće izdvojene vokativne komunikacijske funkcije jesu dozivanje, obraćanje i oslovljavanje sugovornika te su one istaknute u pet od šest promatranih udžbenika (HBZ, str. 53; HJN, str. 116; HK, str. str. 55; HZ5, str. 111) kao što je prikazano u Tablici 6. Slično je određenje prisutno u Gramatici hrvatskoga jezika u kojoj je vokativ predstavljen kao padež oslovljavanja, obraćanja i dozivanja (Težak i Babić, 2016, str. 297) i Školskoj gramatici u kojoj je navedena uloga vokativa imenovanje sugovornika s izravnim obraćanjem, pri kojemu vokativ daje obavijest o identitetu osobe s kojom se uspostavlja komunikacija (Ham, 2017, str. 54). Jedan udžbenik (VH, str. 43) napominje razliku između dviju vokativnih funkcija 
(dozivanja i obraćanja sugovorniku) s primjerima, što predstavlja višu razinu zadiranja u komunikacijsku sferu od samoga taksativnoga navođenja padežnih uloga. Podsjetimo, riječ je o udžbeniku koji je i sintaktička vokativna obilježja detaljnije obradio u odnosu na ostale. U jednomu od šest udžbenika (NH, str. 47) vokativna uloga nije izrijekom navedena, već je pripisana usklicima koji služe dozivanju ili oslovljavanju koga, međutim vokativni se oblik, kao i njegova pragmatička domena mogu ostvariti i bez posredstva usklika, čija je funkcija zapravo intenzifikacija semantičke okosnice vokativnoga izraza. U četirima udžbenicima istaknuto je i podrijetlo imena vokativ koje potječe od latinskoga vocare u značenju zvati, čime se indirektno učenike upućuje na vokativnu funkciju dozivanja (HBZ, str. 53; HZ5, str. 110; NH, str. 46; VH, str. 43). Zanimljivo je promotriti koje se još funkcije vezuju za vokativ. U određenim je udžbenicima prisutna emotivna funkcija vokativnoga izraza kojom se nazire i koncepcija njegove polisemičnosti te se ipak dublje ponire u područje njegovih semantičko-pragmatičkih obilježja. Naime, u jednome je od šest udžbenika (HZ5) zabilježeno kako vokativ služi za izražavanje dragosti i dopadanja (HZ5, str. 111), čime se otkriva subjektivna motiviranost vokativnoga izraza i takozvani vokativ emocija (v. Skljarov, 1962, str. 409-410). Štoviše, također u jednome od šest udžbenika (HBZ) koji bilježi podrobniji pristup vokativnim komunikacijskim funkcijama, a prethodno je potvrđen kao onaj s manjom razinom morfološke usmjerenosti, navedeno je kako vokativ služi za izricanje različitih osjećaja (zabrinutost, razočarenje, prijekor, poticaj) i stajališta prema sugovorniku (HBZ, str. 54). Dakle, ne samo pozitivnih, već i negativnih emocija, ali i stavova, čime se dodatno produbljuje koncept emfatičnosti i semantičke markiranosti vokativnoga izraza u vidu vokativa emocionalne reakcije odnosno vokativa emocionalne ocjene kojima govornik označava sugovornika (v. Babić, 2011, str. 51). U navedenim je dvama udžbenicima učinjen znatan iskorak u odnosu na ostale promatrane udžbenike jer u obzir uzimaju suvremene funkcionalne padežne koncepcije, odnosno njegove komunikacijske uloge koje su posebno važne za poučavanje vokativa s obzirom na njegovu inherentnu konativnu ${ }^{15}$ jezičnu funkciju usmjerenu na primatelja poruke. Usto, jasno je istaknuta i višeznačnost vokativnoga izraza u vidu usmjerenosti na njegovu emocionalno domenu.

15 Klasifikacija jezičnih funkcija prema Jakobson, R. (1966). Lingvistika i poetika. Nolit. 
P. Božanić: Obrada vokativnih obilježja u suvremenim udžbenicima ...

Tablica 6. Vokativne komunikacijske funkcije u osnovnoškolskim udžbenicima

\begin{tabular}{lcccccc}
\hline \multirow{2}{*}{ Komunikacijska funkcija } & \multicolumn{7}{c}{ Udžbenik } \\
\cline { 2 - 6 } & HBZ & HJN & HK & HZ5 & NH & VH \\
\hline dozivanje & + & + & + & + & & + \\
obraćanje & + & + & + & + & & + \\
oslovljavanje & + & + & + & & & \\
izražavanje različitih osjećaja i & + & & & + & & \\
stajališta prema sugovorniku & & & & & & \\
\hline
\end{tabular}

SREDNJOŠKOLSKI UDŽBENICI I ŠKOLSKE GRAMATIKE (SILIĆ I PRANJKOVIĆ, 2007; HUDEČEK I MIHALJEVIĆ, 2019)

Prema Odluci o donošenju kurikuluma za nastavni predmet Hrvatski jezik za osnovne škole i gimnazije u Republici Hrvatskoj (NN 10/2019) i Odluci o donošenju kurikuluma za nastavni predmet Hrvatski jezik za srednje strukovne škole na razini 4.2. u Republici Hrvatskoj (NN 10/2019), tj. Kurikuluma nastavnog predmeta Hrvatski jezik za osnovne škole i gimnazije (2019) i Kurikuluma nastavnog predmeta Hrvatski jezik za srednje strukovne škole na razini 4.2. (2019) eksperimentalnoga programa Škola za život, prijedlog razrade odgojno-obrazovnoga ishoda SŠ HJ A.3.5. u vidu obrade padeža u trećemu razrednu srednje škole odnosi se na razlikovanje gramatičkih kategorija riječi na zadanim primjerima u kontekstu. Ovaj se ishod, još u većoj mjeri nego li je to slučaj s osnovnoškolskim, usmjerava prema formalno-gramatičkome tumačenju padeža, stoga se očekuje čvrsta morfološka tendencija obrade vokativnih obilježja.

Pojam padeža u dvama je analiziranim udžbenicima određen u kontekstu promjene oblika imenica (P, str. 67) i gramatičke kategorije riječi (LR, str. 79), što se ne udaljava od plošnijih osnovnoškolskih udžbeničkih određenja. S druge strane, u ostalim dvama udžbenicima iskazana je preciznija razina definiranja u vidu izricanja različitih odnosa među riječima, tj. između značenja riječi i rečeničnoga sadržaja (FF, str. 68; HJK, str. 170) i, štoviše, upućivanje na to da određena imenica nije upotrijebljena u određenom padežu jer odgovara na svojstveno padežno pitanje, nego je upotrijebljena u tome padežu jer on ima određeno značenje (HJK, str. 170). Silić i Pranjković (2007, str. 38) u Gramatici hrvatskoga jezika za gimnazije i visoka učilišta te Hudeček i Mihaljević (2019, str. 54, 234) padež svrstavaju pod morfološku, tj. gramatičku kategoriju kojom se gramatičkim morfemima uspostavljaju veze među riječima decidirano naglašavajući oblikotvornu padežnu odrednicu.

Obrada vokativnih fonoloških obilježja uočena je u jednome od četiriju udžbenika i to u kontekstu glasovne promjene palatalizacije u jedninskim vokativnim oblicima imenica muškoga roda (LR, str. 97). Iako se navode osobitosti imenica određene sklonidbene vrste, vokativna fonološka obilježja u ostalim 
trima udžbenicima (FF, HJK i P) nisu istaknuta. Iz ovoga se dade razlučiti kako u većini srednjoškolskih udžbenika fonološka obilježja nisu ocijenjena kao važna isticanja prilikom obrade vokativnih specifičnosti, poglavito u usporedbi s osnovnoškolskim udžbenicima. Silić i Pranjković $(2007$, str. 28, 99) u svojoj gramatici napominju palatalizaciju koju nazivaju prvom palatalizacijom s glasovima $c, k, g$ i $h$ koji ispred gramatičkoga morfema -e prelaze u glasove $\check{c}, \check{z}$ i $\check{s}$ i drugu palatalizaciju, odnosno sibilarizaciju za množinske vokativne oblike $\mathrm{u}$ kojima glasovi $k, g$ i $h$ ispred gramatičkoga morfema -i prelaze u glasove $c$, $z$ is (junak > junaci, strateg > stratezi, zloduh > zlodusi) (Silić i Pranjković, 2007, str. 29). Hudeček i Mihaljević (2019, str. 38) za vokativne oblike bilježe glasovnu promjenu palatalizacije. Silić i Pranjković (2007, str. 101) bilježe i višestruke glasovne promjene $\mathrm{u}$ oblicima $\mathrm{u}$ kojima dolazi do raspodjele fonema $s t c$ i $z d c$, pri čemu se događa ispadanje suglasnika $t$ i $d$ (petoprstac $>$ petoprstče $>$ petoprsče, grozd $>$ grozdče $>$ grozče), potom dolazi do jednačenja po mjestu tvorbe nenepčanika $s$ ispred nepčanika $\check{c}$ u nepčanik $\check{s}$ (petoprsče $>$ petopršče), a u slučaju raspodjele fonema $z d c$ tomu prethodi jednačenje po zvučnosti zvučnoga $b$ ispred bezvučnoga $\check{c}$ u bezvučni $s$ (grozče $>$ grosče $>$ grošče). Dotiču se i određenih fonetskih vokativnih obilježja napominjući kako u oblicima koji u nominativu završavaju na -ac u kosim padežima dolazi do glasovne promjene nepostojanoga $a$ prilikom raspodjele fonema $d l, d r, n \check{c}, s l$, sn i $t l$, pri čemu se mijenja naglasak tih imenica (pòdlac > podlàca), međutim u vokativu jednine naglasak se vraća, stoga je isti kao i u nominativu (pòdlac - pòdlače) (Silić i Pranjković, 2007, str. 101-102). Hudeček i Mihaljević (2019, str. 64-65) također navode višestruke glasovne promjene u oblicima vrabac > vrapče/vrapci (nepostojano $a$, jednačenje po zvučnosti, palatalizacija za jedninski oblik) i ronilac > ronioče/ronioci (nepostojani $a$, vokalizacija, palatalizacija za jedninski oblik). U Silićevoj i Pranjkovićevoj gramatici i onoj Hudeček i Mihaljević zabilježena je detaljnija usmjerenost prema vokativnim fonetskim i fonološkim obilježjima u odnosu na prethodne gramatike, što je dijelom i razumljivo s obzirom na ciljanu skupinu, odnosno višu razinu obrazovanja. Međutim, prikazom fonoloških obilježja u Gramatici hrvatskoga jezika za gimnazije i visoka učilišta i Hrvatskoj školskoj gramatici još se više ističe zanemarivanje tih vokativnih značajka u promatranim srednjoškolskim udžbenicima.

Kao vokativne morfološke značajke u trima udžbenicima (FF, LR i P) navedeni su gramatički morfemi -a (za imenice poput tetka, ujna, strina i muška imena na -a kao Andrija, Toma), -e (apelativi na -ica kao mamice, sestrice te muška i ženska imena na -a kao Ivice, Dragice) i -o (kao najfrekventniji gramatički morfem za imenice ženskoga roda) za imenice ženskoga roda e-sklonidbe (LR, str. 97), potom vokativni jedninski gramatički morfem -e za imenice muškoga roda čija osnova završava nenepčanikom (FF, str. 72; P, str. 71) i -u za imenice muškoga roda čija osnova završava nepčanikom (FF, str. 72), zatim se spominju i dvojni oblici nastali pod utjecajem nekadašnjega nepčanoga $r$ 
(mornare, mornaru) (FF, str. 72$)$ te raspodjela gramatičkih morfema imenica muškoga roda: -o, -u i ništični morfem (-ø) (P, str. 71). Jedan od četiriju udžbenika (HJK) posebno se ne osvrće na specifičnosti vokativnih oblika, tj. njihovih gramatičkih morfema.

Tablica 7. Morfološka vokativna obilježja u srednjoškolskim udžbenicima

\begin{tabular}{lcccc}
\hline \multirow{2}{*}{ Morfološko obilježje } & \multicolumn{4}{c}{ Udžbenik } \\
\cline { 2 - 5 } & FF & HJK & LR & P \\
\hline N jd. -ar, -er > V jd. -e/-u & + & & \\
osnova na nepčanik > V jd. -e & + & & \\
osnova na nenepčanik $>$ V jd. -u & + & & & \\
prezimena u V & & & & + \\
imena u V & + & & + & + \\
raspodjela gram. morfema s & + & & & \\
obzirom na rod imenice & & & & \\
\hline
\end{tabular}

Iz Tablice 7. razvidno je kako ni u srednjoškolskim udžbenicima oblikotvorne vokativne odrednice nisu usuglašene, a može se primijetiti kako su u odnosu na osnovnoškolske udžbenike i nepotpunije opisane jer, primjerice, ne spominju sinkretizam nominativnih i vokativnih oblika te specifičnosti vokativnih oblika antroponima, odnosno imena i prezimena, što je naznačeno u pojedinim osnovnoškolskim udžbenicima. Dakle, umjesto potencijalnoga očekivanog proširivanja nastavnoga sadržaja padežnih oblikotvornih obilježja, u srednjoškolskim udžbenicima dolazi do njihove redukcije u vidu obrade vokativa, čime se nameće zaključak kako vokativ i kategorija vokativnosti nisu ocijenjeni kao relevantan nastavni sadržaj. Naime, tri od četiriju udžbenika donose dvije specifičnosti vokativnih gramatičkih morfema, a u jednome od četiriju udžbenika one nisu ni spomenute, što može kao i u osnovnoškolskim udžbenicima upućivati na veću usmjerenost na sintaktička i komunikacijska obilježja, što ćemo vidjeti u nastavku. Silić i Pranjković (2007, str. 98-99) u svojoj gramatici bilježe množinski sinkretizam nominativnih i vokativnih gramatičkih morfema, kao i raspodjelu gramatičkih morfema s obzirom na (ne)nepčanik za imenice muškoga roda, što je zabilježeno i u Hudeček i Mihaljević (2019, str. 58-59). Kao što je već spomenuto, Silić i Pranjković (2007, str. 109) osvrću se na distribuciju gramatičkih morfema za ženska imena bilježeći dvojne gramatičke morfeme -a i -o, ali i na imenice ženskoga roda na -ic-a koje inače imaju gramatički morfem -e (apelativi - prijateljice, ženska imena - Marice, muška imena - Ivice), no neke od njih mogu značiti muški i ženski spol (izdajica, izjelica, kukavica, propalica) kojima bilježe dvojne gramatičke morfeme -e i -o (primjerice, izdajice/ izdajico $)^{16}$ (Silić i Pranjković, 2007, str. 108-109), čime produbljuju vokativne

16 Pojava se gramatičkoga morfema -o može objasniti njegovom stilogenosti sa značenjskim dispozicijama antipatetičkoga odnosa govornika prema sugovorniku (Težak, 1982, str. 40). 
morfološke specifičnosti u odnosu na Hrvatsku školsku gramatiku u kojoj pored prikaza sklonidbenih obrazaca nisu podrobnije istaknuta pravila distribucije vokativnih gramatičkih morfema.

U kontekstu sintaktičkih obilježja u svim se udžbenicima spominje vokativna autonomnost u odnosu na ostale rečenične članove (FF, str. 68; HJK, str. 170; LR, str. 79; P, str. 71), a u dvama je udžbenicima naglašeno i pravopisno pravilo odvajanja vokativa zarezom (FF, str. 68 ; $\mathrm{P}$, str. 71) s primjerom o važnosti njegove primjene u pismima i e-porukama u jednome od tih udžbenika $(\mathrm{P}$, str. 71). Svi se udžbenici osvrću na usklike kao indikatore vokativnoga izraza (FF, str. 68; HJK, str. 170; LR, str. 79; P, str. 67), a u jednome od njih napomenuto je kako vokativ ne čini padežno-prijedložni izraz (P, str. 67). Kao i u slučaju s fonološkim i morfološkim obilježjima, u srednjoškolskim je udžbenicima i o pitanju sintaktičkoga statusa vokativa prisutan osnovan pregled, čime se opet u odnosu na osnovnoškolske udžbenike vokativne značajke prikazuju djelomičnije, što je jasno naznačeno u Tablici 8.

Tablica 8. Sintaktička vokativna obilježja u srednjoškolskim udžbenicima

\begin{tabular}{lcccc}
\hline \multirow{2}{*}{ Sintaktičko obilježje } & \multicolumn{5}{c}{ Udžbenik } \\
\cline { 2 - 5 } & FF & HJK & LR & P \\
\hline autosintaktičnost & + & + & + & + \\
vokativni izraz besprijedložan & & & & + \\
\hline
\end{tabular}

U gramatici Hudeček i Mihaljević (2019, str. 243) nisu naglašene vokativne sintaktičke funkcije, već je on određen kao peti padež koji dolazi uz uzvike. No to nije slučaj sa Silićevom i Pranjkovićevom gramatikom. Oni, naime, pozornost posvećuju sintaktičkoj službi vokativa u rečenici promatrajući ga čak kao sintaktičko-semantičku kategoriju koju u tome slučaju nazivaju obraćanjem jer vokativ kao morfološka kategorija prvotno služi određivanju paradigmatskih odnosa vokativnoga izraza prema ostalim padežima, no izdvaja se iz strukture na razini sintagmatske osi, stoga bi povoljnije određenje u sintaktičkome kontekstu bio termin obraćanje kao ostvarivanja relacija kategorije vokativnosti s ostalim jedinicama (Pranjković, 1993, str. 205). Time se udaljavaju od tradicionalnoga gramatičarskoga uporišta otvaranjem pitanja vokativnih značenja i odnosa s ostalim članovima rečeničnoga ustrojstva. Uspoređuju vokativ s imperativom zbog orijentiranosti na sugovornika čime ističu njegovu komunikacijsku funkciju oslovljavanja i inherentnu konativnu jezičnu funkciju (Silić i Pranjković, 2007, str. 200). U relaciji s ostalim padežima vokativ je opisan kao najsamostojniji, a njegova se sintaktička samostalnost u vidu rečenice specifične vrste, čija je uloga obraćanje sugovorniku i vokacija za uspostavom komunikacijskoga čina, ogleda odvajanjem zarezom kao isticanje pravopisnoga obilježja, a naznačena je i slobodna pozicija vokativa u rečenici (Silić i Pranjković, 2007, str. 200). Navode kako vokativ nerijetko dolazi zajedno u konstrukciji 
s uzvikom zbog ekvivalentne funkcije oslovljavanja govornika s uzvicima $e j$ ili oj kao oznakama prepoznatljivosti vokativnoga izraza (Silić i Pranjković, 2007, str. 200). Karakterističnost takva jezičnoga strukturiranja jest uskličnost determinirana specifičnom uskličnom intonacijom s pojačanim intenzitetom govorne realizacije i znakom uskličnika ili kombinacijom znakova upitnika i uskličnika (Silić i Pranjković, 2005, str. 200). Unatoč svojoj sintaktičkoj nezavisnosti, vokativ je određen komunikativnom suznačnosti, ${ }^{17}$ odnosno pripada suznačnim oblicima riječi jer njegova funkcija pretpostavlja ostvarivanje govorne situacije pozivom sugovornika na interakciju (Silić i Pranjković, 2007, str. 242). No u određenim situacijama vokativ djeluje u službi samoznačnoga oblika, kao što je slučaj kada vokativ preuzima funkciju nominativa u, najčešće, usmenome narodnome pjesništvu gdje je stilski obilježen, a njegova služba u rečenici predstavlja subjekt (Kada li ih pokrijepio starče, / Sva se družba ižljubila redom) (Silić i Pranjković, 2005, str. 296).

Što se tiče vokativnih pragmatičko-semantičkih karakteristika u srednjoškolskim udžbenicima, one su prikazane s osnovnim vokativnim komunikacijskim funkcijama dozivanja, obraćanja i oslovljavanja (FF, str. 68; HJK, str. 171; LR, str. 79; P, str. 67), što je posebno istaknuto u Tablici 9. U gramatici se Hudeček i Mihaljević (2019, str. 55) posebno ne izdvajaju vokativne komunikacijske uloge, osim napomene kako se u starijim hrvatskim gramatikama vokativ nazivao kao zovnik, zvanik ili zvateljan padež iz čega se mogu nazrijeti njegove pragmatičke osobine.

Tablica 9. Vokativne komunikacijske funkcije u srednjoškolskim udžbenicima

\begin{tabular}{lcccc}
\hline \multirow{2}{*}{ Komunikacijska funkcija } & \multicolumn{4}{c}{ Udžbenik } \\
\cline { 2 - 5 } & FF & HJK & LR & P \\
\hline dozivanje & + & + & + & + \\
obraćanje & + & + & + & \\
oslovljavanje & + & & & \\
\hline
\end{tabular}

Iz svega se navedenog može primijetiti kako su vokativna obilježja u srednjoškolskim udžbenicima prikazana prilično površno bez većih zadiranja u fonološke, sintaktičke, semantičko-pragmatičke, pa čak i očekivane morfološke odrednice. Štoviše, razvidno je kako su u osnovnoškolskim udžbenicima navedene vokativne značajke podrobnije obrađene. S obzirom na višu razinu obrazovanja, mogao se očekivati razvoj i dogradnja padežnih značenja u odnosu

17 „Suznačne (sinsemantične) riječi i, rjeđe, suznačni oblici čine zatvorene skupove jezičnih jedinica. Svima im je zajedničko to što ne mogu zauzimati poziciju ni samostalnih ni nesamostalnih članova rečeničnoga ustrojstva. (...) U prvu skupinu idu izrazito gramatikalizirane, nesamostalne riječi i oblici, i to prijedlozi, veznici i jedan dio čestica (...) te oblici pomoćnih, modalnih, faznih i perifraznih glagola, dok u drugu idu uzvici, oblici vokativa (u službi obraćanja) i dio čestica“" (Silić i Pranjković, 2005, str. 242). 
na osnovnoškolske udžbenike, međutim to je izostalo, što govori o čvršćoj usmjerenosti srednjoškolskih udžbenika na formalno-pojmovni pristup obradi vokativa.

\section{ZAKLJUČAK}

U radu su se analizirali udžbenici hrvatskoga jezika za osnovnu i srednje škole koji su u upotrebi u tekućoj školskoj godini (2020./2021.) te četiri školske gramatike, Gramatika hrvatskoga jezika za gimnazije i visoka učilišta (2007) Josipa Silića i Ive Pranjkovića, Gramatika hrvatskoga jezika: priručnik za osnovno jezično obrazovanje (2016) Stjepka Težaka i Stjepana Babića, Školska gramatika hrvatskoga jezika (2017) Sande Ham i Hrvatska školska gramatika (2019) Lane Hudeček i Milice Mihaljević. Kriterij analize bila je obrada vokativnih obilježja na fonetskoj, fonološkoj, morfološkoj, sintaktičkoj, pravopisnoj i pragmatičko-semantičkoj razini kako bi se dobila cjelovita slika poimanja vokativa u nastavi hrvatskoga jezika i ustvrdila razina formalno-gramatičkoga odnosno komunikacijsko-funkcionalnoga koncepta jezikoslovne paradigme proučavanja padeža.

Pri određenju pojma padeža uočeno je kako svi osnovnoškolski udžbenici i polovica srednjoškolskih udžbenika padež određuje kao morfološku kategoriju u vidu promjene oblika iste imenice, a školske gramatike i druga polovica srednjoškolskih udžbenika svoja određenja temelje na izricanju odnosa imenica s ostalim riječima. Iako se prema načelu primjerenosti u nastavi hrvatskoga jezika prva definicija može činiti prihvatljivom u osnovnoškolskoj nastavi, na razini srednje škole potrebno je njezino podrobnije objašnjenje s obzirom na padežne uloge i značenja.

Poučavanje vokativa u osnovnoškolskim udžbenicima različito je raspoređeno, misleći na redoslijed poučavanja padeža, stoga se u trima od šest udžbenika vokativ poučava kao posljednji padež, u jednome od njih kao šesti padež, $\mathrm{u}$ jednome kao peti padež, a u jednome zajedno s nominativom.

Što se tiče vokativnih naglasnih obilježja, ona nisu posebno istaknuta ni u udžbenicima ni u promatranima gramatikama. Za fonološka se vokativna obilježja vezuju glasovne promjene determinirane specifičnim morfološkim kontekstom, a u osnovnoškolskim udžbenicima najčešće je to palatalizacija uz potvrdu sibilarizacije i nepostojanoga $a$ u jednome udžbeniku, što u srednjoškolskim udžbenicima nije posebno naznačeno, točnije glasovna promjena palatalizacije zabilježena je u jednome udžbeniku. Iz ovoga je razvidno kako su vokativna fonološka obilježja detaljnije obrađena u osnovnoškolskim udžbenicima. U školskim se gramatikama pozornost također posvećuje palataliziranim vokativnim oblicima, no u gramatici Hudeček i Mihaljević registrirane su višesložne glasovne promjene u jednome vokativnome obliku (primjerice nepostojani $a$, jednačenje po zvučnosti, palatalizacija) te Silićevoj i Pranjkovićevoj 
gramatici u kojoj su zabilježene glasovne promjene ispadanja glasova i jednačenja po mjestu tvorbe (te jednačenja po mjestu zvučnosti) pri raspodjeli fonema $s t c$ i $z d c$.

Pravopisna pravila vezana za vokativ naznačena su u svim analiziranim udžbenicima s obzirom na pisanje zareza, tj. odvajanje vokativnoga oblika zarezom od ostatka rečenice, a u dvama se osnovnoškolskim udžbenicima spominje i odvajanje zarezom vokativnoga izraza s primjerima strukture atributne ili apozitivne sintagme, čime se dotiče problematike oblikovanja, odnosno označavanja sintagmatskoga modela vokativnoga izraza.

Morfološka su vokativna obilježja u kontekstu raspodjele vokativnih gramatičkih morfema podrobno obrađena u četirima od šest osnovnoškolskih udžbenika, što je slučaj i s promatranim školskim gramatikama, posebno Težakovom i Babićevom gramatikom, no u ostalim dvama osnovnoškolskim udžbenicima ona nisu zabilježena, pri čemu oni pokazuju veću usmjerenost na detaljniji prikaz sintaktičkih odnosno pragmatičko-semantičkih vokativnih značajka. U srednjoškolskim je udžbenicima zabilježena manja razina obrade vokativnih oblikotvornih karakteristika, tj. manji broj registriranih morfoloških obilježja u odnosu na osnovnoškolske udžbenike.

Sintaktička su obilježja cjelovito obrađena u svim osnovnoškolskim udžbenicima doticanjem značajke asintaktičnosti, autosintaktičnosti, vokativnoga izraza koji se tvori bez prijedloga i ne odgovara na padežna pitanja, a u jednome se od šest udžbenika spominje i slobodna pozicija vokativa u rečenici. U srednjoškolskim udžbenicima opet je prikazana manja razina obrade vokativnih sintaktičkih obilježja u odnosu na osnovnoškolske i to u znatnoj mjeri jer je istaknuta samo vokativna autosintaktičnost i besprijedložnost vokativnoga izraza. Što se tiče školskih gramatika, Silićeva i Pranjkovićeva donosi koncept vokativa, odnosno kategorije vokativnosti kao obraćanja u vidu sintaktičko-semantičke kategorije odmičući se tako od formalno-gramatičkoga pristupa.

Pragmatičko-semantička vokativna obilježja u osnovnoškolskim i srednjoškolskim udžbenicima uglavnom su usmjerena na navođenje komunikacijskih funkcija dozivanja, obraćanja i oslovljavanja, no u dvama osnovnoškolskim udžbenicima ona su proširena i izricanjem različitih osjećaja i stavova prema sugovorniku, čime se iskazuje polisemičnost vokativnoga izraza i njegova emotivna funkcija te njihova usmjerenost na komunikacijsko-funkcionalni pristup.

Sagledavši gramatičarska i udžbenička određenja padeža kao jezikoslovnoga pojma, kao i kurikulne smjernice, uočljivo je kako je morfološka odrednica glavni kriterij njegova definiranja potvrdivši tako početnu pretpostavku, pri čemu se prati čvrsto utemeljene formalno-gramatičke gramatikološke stavove, a koncepti vokativnih padežnih značenja, uloga i njihove upotrebe u većini slučajeva posve su zanemareni ili se pak skromno naziru. Posebno je indikativno da su vokativna obilježja na svim promatranim razinama podrobnije obrađena u osnovnoškolskim nego u srednjoškolskim udžbenicima. 
Ovim se radom otvorilo pitanje obrade vokativnih obilježja u nastavi, kao i implementacija jezikoslovnih padežnih paradigma u udžbenicima hrvatskoga jezika. Željelo se skrenuti pozornost na važnost sveobuhvatnog poimanja jezičnih fenomena, a poglavito padeža, odnosno vokativa u padežnome sustavu hrvatskoga jezika. Za buduća istraživanja ove problematike bilo bi korisno promotriti i poimanje obilježja ostalih padeža, proširiti korpus školskih gramatika s dijakronijskim pregledom, kao i analizirati metodičke te praktične smjernice obrade vokativnih obilježja u udžbenicima hrvatskoga jezika.

\section{IZVORI}

1. Družijanić-Hajdarević, E., Greblički-Miculinić, D., Matošević, K. i Romić, Z. (2020). Hrvatski za 5: udžbenik iz hrvatskoga jezika za peti razred osnovne škole. Profil Klett.

2. Dujmović Markusi, D. i Španjić, T. (2020). Fon-Fon 3: udžbenik hrvatskoga jezika za treći razred gimnazije i srednjih strukovnih škola. Profil Klett.

3. Ham, S. (2017). Školska gramatika hrvatskoga jezika. Školska knjiga.

4. Hudeček, L. i Mihaljević, M. (2019). Hrvatska školska gramatika. Institut za hrvatski jezik i jezikoslovlje.

5. Kovač, S. i Jukić, M. (2019). Hrvatska krijesnica 5: udžbenik iz hrvatskoga jezika za 5. razred osnovne škole. Ljevak.

6. Levak, J., Močibob, I., Sandalić, J., Pettò, I. i Budija, K. (2020). Hrvatski bez granica 5: integrirani udžbenik hrvatskoga jezika i književnosti za peti razred osnovne škole. Školska knjiga.

7. Marčan T. i Grubišić Belina, L. (2020). Putokazi 3: udžbenik za hrvatski jezik, književnost i komunikacijske vještine 21. stoljeća za 3. razred strukovnih škola na razini 4.2 i gimnazije. Školska knjiga.

8. Miloloža, S., Cikuša, R., Šimić, D. i Petrović, B. (2020). Hrvatske jezične niti 5: udžbenik iz hrvatskoga jezika za peti razred osnovne škole. Alfa.

9. Rihtarić, A., Latin, S. i Majić, Ž. (2020). Volim hrvatski 5: udžbenik hrvatskoga jezika u petome razredu osnovne škole. Školska knjiga.

10. Serdarević, K., Čubrić, M., Gligorić, I. M. i Medić, I. (2020). Hrvatski jezik $i$ književnost 3: integrirani udžbenik hrvatskoga jezika za treći razred gimnazije. Školska knjiga.

11. Silić, J. i Pranjković, I. (2007). Gramatika hrvatskoga jezika za gimnazije i visoka učilišta. Školska knjiga.

12. Šojat, A. (2020). Naš hrvatski 5: udžbenik hrvatskoga jezika u petome razredu osnovne škole. Školska knjiga.

13. Težak, S. i Babić, S. (2016) Gramatika hrvatskoga jezika: priručnik za osnovno jezično obrazovanje. Školska knjiga.

14. Zrinjan, S. (2020a). Biram knjigu i riječ 3: čitanka i udžbenik iz hrvatskoga jezika za treći razred strukovnih škola. Alfa. 
P. Božanić: Obrada vokativnih obilježja u suvremenim udžbenicima ...

15. Zrinjan, S. (2020b). Lica riječi 3: udžbenik iz hrvatskog jezika za treći razred gimnazija i četverogodišnjih strukovnih škola. Alfa.

\section{LITERATURA}

1. Babić, M. (2010). Obraćanje kao primarna funkcija vokativa. Radovi Filozofskog fakulteta u istočnom Sarajevu, 2(12), 325-338.

2. Babić, M. (2011). Vokativ kao sredstvo za izražavanje ekspresivnosti. Radovi Filozofskog fakulteta u istočnom Sarajevu, 1(13), 45-66.

3. Babić, S., Brozović, D., Škarić, I. i Težak, S. (2007). Glasovi i oblici hrvatskoga književnog jezika. Nakladni zavod Globus.

4. Badurina, L. (2010). Padeži i komunikacija. U M. Birtić i D. Brozović Rončević (ur.), Sintaksa padeža - Hrvatski sintaktički dani 2 (str. 1-14). Institut za hrvatski jezik i jezikoslovlje i Filozofski fakultet u Osijeku.

5. Barić, E., Lončarić, M., Malić, D., Pavešić, S., Peti, M., Zečević, V. i Znika, M. (2005). Hrvatska gramatika. Školska knjiga.

6. Belaj, B. i Tanacković Faletar, G. (2014). Kognitivna gramatika hrvatskoga jezika. Disput.

7. Bičanić, A. (2009). Imenice hrvatskoga standardnog jezika u nastavi hrvatskoga jezika od petoga do osmoga razreda osnovne škole. Hrvatski, 7(1), 33-68.

8. Borucinsky, M. i Tominac Coslovich, S. (2015). Formalno i funkcionalno u jeziku: sistemska funkcionalna gramatika u odnosu na ostale funkcionalne gramatike i kognitivnolingvističke pristupe. Fluminensia, 27(2), 11-29.

9. Božanić, P. (2020). Vokativ u hrvatskim dopreporodnim gramatikama. Mogućnosti, 60(1/2), 37-55.

10. Daniel, M. i Spencer, A. (2009). The Vocative - An Outlier Case. U A. Malchukov i A. Spencer (ur.), The Oxford Handbook of Case (str. 626-635). University Press.

11. Glušac, M. i Mikić Čolić, A. (2017). Linguistic Functions of the Vocative as a Morphological, Syntactic and Pragmatic-semantic Category. Jezikoslovlje, 18(3), 447-472.

12. Ham, S. (2006). Povijest hrvatskih gramatika. Nakladni zavod Globus.

13. Hudeček, L. (2006). Nova gramatika hrvatskoga jezika. Rasprave, 32(1), 379-382.

14. Jakobson, R. (1966). Lingvistika i poetika. Neolit.

15. Jelaska, Z. (2006). Padežni izazov: hrvatska sklonidba i određivanje padeža. Metodički profili, 3-4, 40-42.

16. Karlić, V. i Okuka, M. (2015). Der morphologische Sprachwandel und seine Ursachen im gegenwärtigen Serbischen und Kroatischen. Wiener Slawistischer Almanach, 85, 81-92.

17. Karlić, V. i Cvitković, I. (2017). Vokativnost u hrvatskoj i srpskoj jezičnoj normi i upotrebi: morfološki pristup. Filološke studije, 15(1), 228-242.

18. Kodrić Gagro, A. i Vraneša, A. (2016). Okamenjivanje: promjene u funkciji padeža u suvremenome hrvatskom jeziku. U S. Botica, D. Nikolić, J. Tomašić i I. 
Vidović Bolt (ur.), Šesti hrvatski slavistički kongres (str. 401-411). Hrvatsko filološko društvo.

19. Kolaković, Z. (2007). Zastupljenost padeža u hrvatskome jeziku u pisanim i govornim tekstovima. Lahor, 2(4), 242-270.

20. Kurikulum nastavnog predmeta Hrvatski jezik za osnovne škole i gimnazije (2019). Republika Hrvatska, Ministarstvo znanosti i obrazovanja.

21. Kurikulum nastavnog predmeta Hrvatski jezik za srednje strukovne škole na razini 4.2. (2019). Republika Hrvatska, Ministarstvo znanosti i obrazovanja.

22. Ljubibratić, R. (1987). Vokativ. Suvremena metodika nastave hrvatskog ili srpskog jezika, 12(1-2), 67-78.

23. Marković, I. (2013). Uvod u jezičnu morfologiju. Disput.

24. Matešić, M. (2006). Gramatika jezične suvremenosti. Fluminensia, 18(1), 144-147.

25. Odluka o donošenju kurikuluma za nastavni predmet Hrvatski jezik za osnovne škole i gimnazije u Republici Hrvatskoj (NN 10/2019) (2019). Republika Hrvatska, Ministarstvo znanosti i obrazovanja.

26. Odluka o donošenju kurikuluma za nastavni predmet Hrvatski jezik za srednje strukovne škole na razini 4.2. u Republici Hrvatskoj (NN 10/2019) (2019). Republika Hrvatska, Ministarstvo znanosti i obrazovanja.

27. Pranjković, I. (1987). Sintaktički status „samostalnih članova rečenice“. Jezik, 35(3), 78-84.

28. Pranjković, I. (1993). Hrvatska skladnja. Hrvatska sveučilišna naklada.

29. Rišner, V. (2006). Iz jezične prošlosti i sadašnjosti. Matica hrvatska, Ogranak Osijek.

30. Skljarov, M. (1962). O vokativu - problem kategorije II lica u imenica. Rad JAZU, $12,381-312$.

31. Stolac, D. (2005). Komunikacijske funkcije vokativa. U I. Pranjković (ur.), Od fonetike do etike (str. 173-184). Disput.

32. Težak, S. (1982). Vokativ jednine imenica E vrste. Radovi zavoda za slavensku filologiju, 17, 31-43.

33. Težak, S. (1986). O vokativu. Jezik, 34(3), 89-92.

34. Težak, S. (1996). Teorija i praksa nastave hrvatskoga jezika 1. Školska knjiga.

35. Težak, S. i Babić, S. (1996). Gramatika hrvatskoga jezika: priručnik za osnovno jezično obrazovanje. Školska knjiga.

36. Trovesi, A. (2008). Il vocativo nelle lingue slave: un quadro articolato. Linguistica e filologia, 26, 207-234.

37. Vlastelić, A. (2013). „O Stvoritelju moj, Božanstveni goste! koliko sam zadužan tebi..." Komunikacijske funkcije vokativa u „Pribogoljubnim bavljenjima za slišati svetu misu" fra Petra Bakule. U P. Knezović i M. Jerković (ur.), Opus fra Petra Bakule (str. 301-311). Hrvatski studiji Sveučilišta u Zagrebu. 